\title{
sciendo
}

DOI: 10.2478/fv-2019-0003

FOLIA VETERINARIA, 63, 1: 17-23, 2019

\section{PREVALENCE OF PORCINE ROTAVIRUS ANTIGEN AND ASSOCIATED RISK FACTORS IN PIG-RAISING COMMUNITIES AND INSTITUTIONAL PIGGERIES IN ZARIA, KADUNA STATE, NIGERIA}

\author{
Delia, T. A. ${ }^{1}$, Dzikwi-Emennaa, A. A. ${ }^{2}$, Kwaga, J. K. P. ${ }^{1}$, Kia, G. S. N. ${ }^{1}$ \\ Olufemi, O. T. ${ }^{2}$, Otolorin, G. R. ${ }^{2}$, Adanu, A. W. ${ }^{2}$ \\ ${ }^{1}$ Department of Veterinary Public Health and Preventive Medicine \\ Faculty of Veterinary Medicine, Ahmadu Bello University, Zaria \\ Kaduna State \\ ${ }^{2}$ Department of Veterinary Public Health and Preventive Medicine \\ Faculty of Veterinary Medicine, University of Jos \\ Plateau State \\ Nigeria
}

temalaa@yahoo.com

\section{ABSTRACT}

Porcine rotaviruses are potential reservoirs for genetic exchange with human rotaviruses. A cross-sectional study was carried out to determine the prevalence of porcine Rotavirus antigen and associated risk factors in pigraising communities and institutional piggeries in Zaria, Kaduna State, Nigeria. A total of 376 faecal samples from pigs of all ages were collected from backyard and institutional piggeries by convenience sampling. The faecal samples collected were analysed using commercially available ELISA kit: BioK 343/2, for the antigenic diagnosis of rotavirus in porcine faeces. The overall prevalence of rotavirus antigen in pigs was $9.8 \%$ (37/376). Piglets $(10.4 \%)$ had a higher prevalence than adults $(9.1 \%)$, while males $(\mathbf{1 0 . 1} \%)$ were more infected than females (9.6\%). Breed-specific prevalences revealed $5.9 \%, 12 \%$ and $15.5 \%$ for local, exotic and cross-breeds, respectively. There was a significant association between breed $(\mathrm{P}<0.05)$ (Odds Ratio OR $=2.927 ; 95 \%$ Confidence Interval $\mathrm{CI}$ on $\mathrm{OR}=1.288-6.653$ ) and rotavirus infection. Management system revealed $14 \%$ and $8.2 \%$ prevalence for intensive and semi-intensive systems, respectively. There is evidence of Rotavirus infection (9.8 \%) in pigs in Zaria, and the breed is a risk factor. This study provides the first data on the prevalence of rotavirus and risk factors of rotavirus infection among pigs in Zaria and environs, Kaduna state, Nigeria. There is a need to enlighten the public on the zoonotic implication and economic impacts of rotavirus infections.

Key words: backyard piggeries; ELISA; institutional piggeries; rotavirus 


\section{INTRODUCTION}

Rotaviruses are important causal agents of diarrhoea in animals, belonging to the family Reoviridae with an elevensegment double-stranded RNA genome [13, 21]. Presently, based on the VP6 structural protein of the genus Rotavirus, ten species designated Rotavirus A-J have been antigenically identified $[4,14,17,21]$. Rotaviruses are generally species-specific, but cross-species transmission is possible. Several case studies have indicated the infection of humans by animal rotaviruses $[20,27]$. Porcine rotavirus is one of the three major causative agents of viral diarrhoea in swine herds worldwide [6], the others being porcine epidemic diarrhoea virus (PEDV) and transmissible gastroenteritis virus (TGEV). Porcine rotavirus infects neonates between the first and the second weeks of life, affecting the productivity of the herd as reflected in the economic losses associated with growth retardation, the cost of veterinary treatment and, in some cases, the death of the animal [26]. These factors make it necessary to develop a diagnostic system that permits the specific detection of porcine rotavirus strains in the affected populations [12]. Rotaviruses can also infect and cause gastroenteritis in a broad range of animal species resulting in significant economic losses in livestock animals, including young hogs and cattle $[13,20]$.

Rotavirus A causes acute enteritis in young piglets and a fairly large proportion of neonatal diarrhoea $[18,19]$. They have been shown to infect mammals (for example apes), cattle, pigs, sheep, rats, cats, dogs, mice, horses, rabbits and birds (chickens and turkeys). These are potential reservoirs for genetic exchange with human rotaviruses [10]. There is evidence for interspecies transmission between humans and other animals as well as between various animal species $[15,20]$. There are two major routes to cross the host barriers: direct interspecies transmission and transmission coupled with reassortment [19]. Management failure in pig herds might be pivotal in the development of the disease, as well as infection by bacteria, protozoa and other viruses [11, 19, 35].

Rotavirus infection is endemic in pig herds worldwide [28]. Antigen detection in diarrhoeic pigs have demonstrated rotavirus infection in two-thirds of herds; and seroprevalence studies in pigs have demonstrated that almost all animals in a herd could be exposed [7, 28]. It therefore becomes important, to screen for the presence of rotavirus in asymptomatic infections [29]. Rotavirus infection in animals can cause great economic loss to the farmer due to the cost of treatment associated with increased morbidity and mortality rates. There is a paucity of information on the prevalence of rotavirus in pigs in Zaria, where very few pigs are mainly raised in traditionally restricted pens. These animals live in close proximity to humans, a situation which may result in significant zoonotic implications with rotavirus infections.

The aim of this study was to investigate the prevalence of rotavirus antigen in the faeces and the risk factors associated with rotavirus infection in pigs in Zaria.

\section{MATERIALS AND METHODS}

\section{Study area}

This study was carried out in Zaria and environ, comprising of Zaria, Sabon Gari and Giwa Local Government Areas (LGAs) in Kaduna State in North-Western Nigeria. Zaria is about 2,800 feet above sea level. It lies on latitude 110 North and 70 42" East [23]. It is characterized by a tropical climate with two main seasons; a rainy season (May to October) and a dry/harmattan season (November to April). The monthly mean temperature records show a range from 13.8 to $36.7^{\circ} \mathrm{C}$ and a mean annual rainfall of $1092.8 \mathrm{~mm}$ [1]. It has an estimated human population of 547,000 and a growth rate of $3.5 \%$ per annum [23]. Hausa and Fulani are the main ethnic groups and their major occupation is agriculture. Approximately $40-70 \%$ of the population derive their livelihood from agriculture $[1,24]$. Animals reared include: cattle, sheep, goats, poultry and pigs.

\section{Study design and sample collection}

A cross-sectional study design was used for the study and convenience sampling method was carried out during sample collection due to the availability of the pigs and consent of the farmers. A sample size of 376 was determined for the study using the formula described by $\mathrm{Th} \mathrm{rusfield}$ [31]. The study subjects were selected regardless of age, sex or breed. For each study subjects, data was generated on the age, sex, breed and other possible risk factors associated with the subject. Fresh faecal samples $(n=376)$ were collected directly from the rectum of well-restrained pigs. The samples collected were transported to the Viral Zoonoses Laboratory in the Department of Veterinary Public Health 
and Preventive Medicine, Ahmadu Bello University Zaria, Nigeria, in separate plastic containers placed on ice-packs and stored at $4{ }^{\circ} \mathrm{C}$ until analysed. The samples were analysed for the presence of rotavirus antigen using enzymelinked immunosorbent assay (ELISA) test kits: ELISA kit, BioK 343/2 (Bio-X Diagnostics, Belgium).

\section{Questionnaire survey}

A total of three hundred and seventy-six (376) structured questionnaires were administered to the farm owners to obtain information on: age, sex, breed, management system, the presence of other animals on the farm, and other biosecurity measures carried out on the farm. For the purpose of this study, some variables are defined as follows: Intensive; animals that are confined at all times and not allowed to scavenge, Semi-intensive; animals that are allowed to scavenge but come back to their pens to be fed. Adult - pig $\geq 4$ months old; piglet $-<4$ months old pig.

\section{Data analysis}

Data obtained from the study as well as the questionnaire survey were subjected to statistical tests using Graph-
Pad Prism version 7.03 for Windows (GraphPad Software, La Jolla California, USA) and Microsoft Excel. The frequency of occurrence of rotavirus in pigs was determined. Chi-square, Fisher's exact test and odds ratios were appropriately calculated where applicable and values of $\mathrm{P}<0.05$ were considered statistically significant.

\section{RESULTS}

This study recorded a $9.8 \%$ prevalence of rotavirus antigen in swine faecal samples obtained from pigs of all ages and from both backyard and institutional piggeries in Zaria and environs. The occurrence was higher in male (10.1\%) pigs than female (9.6\%) pigs (Table 1$)$. It was also slightly higher in piglets (10.4\%) than adult (9.1\%) (Table 1). The breed prevalence was highest in the crossbred pigs $(15.5 \%)$, followed by the exotic $(12.0 \%)$ and lowest in the local pigs (5.9\%) (Table 1). There was a statistically significant relationship $(\mathrm{P}>0.05)$ between the prevalence of rotavirus antigen and breed (Table 1).

The prevalence of rotavirus infection and risk factors

Table 1. Prevalence of porcine rotavirus antigen in relation to age, sex, breed and management system of pigs sampled in Zaria, Kaduna State, Nigeria

\begin{tabular}{|c|c|c|c|c|c|}
\hline Variables & $\begin{array}{l}\text { Number } \\
\text { sampled }\end{array}$ & $\begin{array}{c}\text { Number positive } \\
{[\%]}\end{array}$ & $\begin{array}{c}\text { Odds Ratio } \\
\text { [OR] }\end{array}$ & $\begin{array}{c}95 \% \\
\mathrm{Cl} \text { on OR }\end{array}$ & P-Value \\
\hline \multicolumn{6}{|l|}{ Age } \\
\hline Pigs $<4$ months & 201 & $21(10.2)$ & 1.16 & $0.58-2.30$ & \multirow{2}{*}{0.672} \\
\hline Pigs $\geq 4$ months & 175 & $16(9.1)$ & & & \\
\hline \multicolumn{6}{|l|}{ Sex } \\
\hline Male & 168 & $17(10.1)$ & 1.06 & $0.54-2.09$ & \multirow{2}{*}{0.871} \\
\hline Female & 208 & $20(9.6)$ & & & \\
\hline \multicolumn{6}{|l|}{ Breed } \\
\hline Local & 187 & $11(5.9)$ & 2.93 & $1.28-6.65$ & \multirow{3}{*}{$0.027^{*}$} \\
\hline Exotic & 92 & $11(12.0)$ & 0.99 & $0.41-2.41$ & \\
\hline Cross & 97 & $15(15.5)$ & Ref. & & \\
\hline \multicolumn{6}{|c|}{ Management system } \\
\hline Intensive & 107 & $15(14.0)$ & 1.83 & $0.91-3.682$ & \multirow[b]{2}{*}{0.086} \\
\hline Semi-Intensive & 269 & $22(8.2)$ & & & \\
\hline Total & 376 & $37(9.8)$ & & & \\
\hline
\end{tabular}

OR — Odds Ratio; $\mathrm{Cl}$ - Confidence Interval on OR; Ref — Reference Point, ${ }^{*}$ - Significant 
as the management was not significant $(\mathrm{P}>0.05)$. The intensive system of management had a higher prevalence (14.0\%) than the semi-intensive system (8.2\%) of management (Table 1). There was a high prevalence seen in pigs from institutional farms $(12.0 \%)$ compared to those in the backyard farms (9.2\%) (Table 1).

The pigs fed on commercial feed revealed a higher prevalence of Rotavirus infection (11.8\%) than pigs that were fed home-made feed and also scavenged (9.2\%). The source of water also yielded a prevalence of $9.2 \%$ and $11.8 \%$ for borehole and dam respectively (Table 2). There was a slightly higher prevalence rate of $13.8 \%$ in farms with other animal species within the pig premises compared to farms with animals far from the pig premises (9.5\%) (Table 2).

\section{DISCUSSION}

The overall prevalence of $9.8 \%$ of rotavirus antigen in the faecal samples of pigs examined in this study, although seemingly low is of public health significance because of the risk of transmission of infection particularly to handlers and pig breeders owing to the fact that rotavirus infected pigs may serve as source of infection to humans [32]. Numerous case reports have indicated human infection incriminating animal strains of rotavirus $[20,33]$. In this study, rotavirus antigen was isolated in apparently healthy pigs. This supports findings of $[3,9,22,29]$, who reported high viral shedding of rotavirus by asymptomatic pigs. This could be as a result of rotavirus being endemic in pig herds worldwide [28]. The presence of rotavirus antigen in asymptomatic pigs in this study is worthy of note as they could be a significant source of new emerging genotypes.

Some studies have recorded higher prevalences than obtained in this study, such as the findings by A $\mathrm{n}$ h et al. [3] in Vietnam, M i d gle y et al [22] and S t e y e r et al. [29] both in Slovenia who recorded prevalence rates of $24.9 \%$, $18 \%$, and $20 \%$, respectively in mostly asymptomatic pigs. Lower prevalence rates were documented by $\mathrm{W}$ e ile $\mathrm{r}$ et al. [34], in Germany and P a r r a et al. [25] in Argentina, with findings of $4 \%$ and $3 \%$, respectively.

The variations in the prevalence of rotavirus infection could be attributed to the study duration, management system, number and age of pigs sampled and season amongst other factors. There was no significant association $(P>0.05)$ between the detection of rotavirus antigen in the faeces and the sex of the pigs sampled. This is an indication that both sexes might have fairly equal chances of being infected with the virus. The prevalence rate of rotavirus infection was higher in the pigs $<4$ months $(10.4 \%)$ than in the pigs $\geq 4$ months $(9.1 \%)(\mathrm{P}>0.05)$. The $<4$ months

Table 2. Association between different risk factors and the prevalence of porcine rotavirus antigen in pigs sampled in Zaria, Kaduna State, Nigeria

\begin{tabular}{|c|c|c|c|c|c|}
\hline Risk factors & $\begin{array}{l}\text { Number } \\
\text { sampled }\end{array}$ & $\begin{array}{c}\text { Number positive } \\
{[\%]}\end{array}$ & $\begin{array}{c}\text { Odds Ratio } \\
\text { (OR) }\end{array}$ & $\begin{array}{c}95 \% \mathrm{Cl} \\
\text { on OR }\end{array}$ & P-Value \\
\hline \multicolumn{6}{|l|}{ Source of feed } \\
\hline Home-made/Scavenging & 284 & $26(9.2)$ & 0.74 & $0.351-1.568$ & \multirow{2}{*}{0.433} \\
\hline Commercial & 92 & $11(11.9)$ & & & \\
\hline \multicolumn{6}{|l|}{ Source of water } \\
\hline Borehole & 284 & $26(9.2)$ & 0.74 & $0.351-1.568$ & \multirow{2}{*}{0.433} \\
\hline Dam & 92 & $11(11.9)$ & & & \\
\hline \multicolumn{6}{|l|}{ Other animals } \\
\hline Present & 29 & $4(13.8)$ & 1.52 & $0.499-4.64$ & \multirow[b]{2}{*}{$0.51^{*}$} \\
\hline Absent & 347 & $33(9.5)$ & & & \\
\hline Total & 376 & $37(9.8)$ & & & \\
\hline
\end{tabular}

OR — Odds Ratio; Cl — Confidence Interval on Odds ratio; Ref — Reference Point, * — Significant 
here include both the suckling and weanling piglets. High morbidity and mortality from rotavirus infection have been reported in nursing and weanling pigs $[5,30]$. A $\mathrm{m}$ i m o et al. [2] also reported a prevalence of $78.7 \%$ in asymptomatic nursing piglets.

The high prevalence of rotavirus antigen detected among the cross breeds and exotic breeds of pigs might be linked to the fact that most of these pigs kept and raised mainly under intensive management system, compared to the local breeds that were kept mostly under the semiintensive or extensive system. Hence faecal-oral transmission of the virus is enhanced as these animals are in close contact with each other over a long period of time and thus infection of one animal can lead to infection of several animals through contamination of food, water, beddings and even contact with faeces of other infected pigs, and infected aerosols [8]. In addition, most of the intensively managed pig farms in the study area had no strict biosecurity measures in place to prevent cross infection between different pens. This is the likely reason for the high prevalence rate (14.0\%) found in the intensively kept animals in relation to the semi-intensive system. The observation showed that pigs on farms that sourced their water from a dam had an increased rotavirus infection. This agrees with findings of other authors where rotaviruses have been found in surface water samples at high concentrations, indicating that exposed water is likely to contribute to rotavirus transmission cycles on farms $[3,16]$.

The slightly higher prevalence rate of $13.8 \%$ in pig farms with other animal species within the pig premises compared to farms with animals far from the pig premises (9.5\%), gives an indication that there is a possibility of interspecies transmission between these animals, as livestock animals kept on the farms may serve as sources of infection to the pigs and vice-versa. This trend of interspecies transmission of the virus has been reported previously $[15,20]$. The high prevalence seen in pigs from institutional farms (12.0\%) compared to those in the backyard farms (9.2\%) might be due to compromised biosecurity in these farms. There is recirculation and spread of infections through contaminated boots from one farm into the other by the workers. Also, the improper cleaning and disinfection of pens and equipment of the farms lacking adequate biosecurity may result in high prevalence as seen here. The use of one feeder for so many animals can lead to the spread of infection when one of the animals gets infected.
The Giwa Local Government Area had the highest rate of infection in comparison to other Local Government Areas. Location of these animals had a statistically significant association with rotavirus infection. Pig farms in this area are raised under the intensive management system. A break in the biosecurity system can lead to transmission of the virus in the farm. The infection of one animal can lead to the transmission of the virus to other animals via contaminated materials in the pen.

\section{CONCLUSIONS}

This study demonstrates that rotavirus antigen is prevalent amongst pigs in the study area. There was an association between the prevalence of rotavirus antigen with breed and location. This study provides for the first time, data on the prevalence and risk factors of rotavirus infection in pigs in pig-raising communities and institutional farms in Zaria and environs, Kaduna state, Nigeria. The occurrence of rotavirus in pigs could lead to economic loss and may pose a zoonotic threat. Improved biosecurity measures and public enlightenment of the pig farmers on personal hygiene to prevent cross species transmission of rotavirus will aid in its prevention and control.

\section{REFERENCES}

1. Agbogu, V. N., Umoh, V. J., Okuofu, C. A., Smith, S. I., Ameh, J. B., 2006: Study of the bacteriological and physicochemical indicators of pollution of surface waters in Zaria, Nigeria. African Journal of Biotechnology, 5 (9), 732-737.

2. Amimo, J. O., Junga, J. O., Ogara, W. O., Vlasova, A. N., Njahira, M. N., Maina, S., et al., 2015: Detection and genetic characterization of porcine group A rotaviruses in asymptomatic pigs in small holder farms in East Africa: Predominance of $\mathrm{P}(8)$ genotype resembling human strains. Vet. Microbiol., 175 (2-4), 195-210. DOI: 10.1016/j.vetmic.2014.11.027.

3. Anh, P. H., Carrique-Mas, J., Cuong, N. V., Hoa, N. T., Anh, N. L., Duy, D. T., et al., 2014: The prevalence and genetic diversity of group A rotaviruses on pig farms in the Mekong Delta Region of Vietnam. J. Vet. Microbiol., 170 (3-4), 258265. DOI: doi: 10.1016/j.vetmic.2014.02.030.

4. Bohl, E. H., Kohler, E. M., Saif, L. J., 1978: Rotavirus as a cause of diarrhoea in pigs. J. Am. Vet. Med. Assoc., 172 (4), 458-463. 
5. Bohl, E. H., 1979: Rotaviral diarrhoea in pigs. J. Am. Vet. Med. Assoc., 174 (6), 613-615.

6. Bohl, E. H., Theil, K. W., Saif, L. J., 1982: Isolation and serotype of porcine rotaviruses and antigenic comparison with other rotaviruses. J. Clin. Microbiol., 19 (2), 105-111.

7. Carvajal, A., Nistal, P. R., 2011: Infection in pigs due to rotavirus. Available at www.pig333.com/diarrhoea during lactation. Retrieved July 10, 2016.

8. Collins, P. J., Martella, V., O’Shea, H., 2008: Detection and characterization of group $\mathrm{C}$ rotavirus in asymptomatic piglets in Ireland. J. Clin. Microbiol., 46 (9), 2973-2979. DOI: 10.1128/JCM.00809-08.

9. Collins, P. J., Martella, V., Sleator, R. D., Fanning, S., O'Shea, H., 2010: Detection and characterization of group A rotavirus in asymptomatic piglets in Southern Ireland. Arch. Virol., 155 (8), 1247-1259. DOI: 10.1007/s00705-010-0713-1.

10. Dewey, C., Wittum, T. E., Hurd, H. S., Dargatz, D. A., Hill, G. W., 1995: Herd-and litter-level factors associated with the incidence of diarrhoea morbidity and mortality in piglets 4-14 days of age. Journal of Swine Health Production, 3 (3), 105-112.

11. Estes, M. K., 1990: Rotaviruses and their replication. In Fields, B. N.: Virology, 2nd edn., Raven Press, New York, 1329-1352.

12. Estes, M. K., Kapikian, A. Z., 2007: Rotaviruses. In Knipe D. M., Howley, P. M.: Fields Virology, 5th edn., Lippincott Williams and Wilkins, USA, 1917-1974.

13. Ha, T. P. M., Kim, H., Saif, L. H., Jeong, Y., Kim, H., Kwon, H., et al., 2009: Sequence analysis of unusual P(7)G5 bovine rotavirus strains reveals evidence of interspecies transmission. J. Clin. Microbiol., 47 (10), 3329-3332. DOI: 10.1128/ JCM.01583-08.

14. He, X., Wei, Y., Cheng, L., Zhang, D., Wang, Z., 2012: Molecular detection of three gastroenteritis ciruses in urban surface waters in Beijing and correlation with levels of faecal bacteria. Enviromental Monitoring and Assessment, 184, 5563-5570. DOI: 10.1007/s10661-011-2362-6.

15. Kapikian, A.Z., Hoshino,Y., Chanock, R. M., 2001: Rotaviruses. In Knipe, D. M., Howley, M., Griffin, D. E., Lamb, R. A., Martin, M. A., Roizman, B., et al.: Fields Virology, 4th edn., Lippincott Williams, Wilkin, Philadelphia, 1787-1833.

16. Katsuda, K., Kohmoto, M., Kawashima, K., Tsunemitsu, H., 2006: Frequency of enteropathogen detection in suckling and weaned pigs with diarrhoea in Japan. J. Vet. Diagn. Invest., 18, 350-354. DOI: 10.1177/104063870601800405.
17. Martella, V., Bányai, K., Matthijnssens, J., Buonavoglia, C., Ciarlet, M., 2010: Zoonotic aspects of rotaviruses. Vet. Microbiol., 140, 246-255. DOI: 10.1016/j.vetmic.2009.08.028.

18. Matthijnssens, J., Van Ranst, M., 2012: Genotype constellation and evolution of group A rotaviruses infecting humans. Current Opinion in Virology. 2: 426-433. DOI: 10.1016/j.coviro.2012.04.007.

19. Midgley, S. E., Banyai, K., Buesa, J., Halaihel, N., Hjulsager, C. K., Jekab, F., et al 2012: Diversity and zoonotic potential of rotaviruses in swine and cattle across Europe. Vet. Microbiol., 156 (3-4), 238-245. DOI: 10.1016/j.vetmic.2011.10.027.

20. Ministry of Economic Development, 1996: Kaduna State Statistical Yearbook, Kaduna, Nigeria. Ministry of Economic Development, Statistics Division.

21. Mortimore, M. J., 1970: Zaria and its Regions: A Nigerian Savannah City and its Environment. Ahmadu Bello University, Zaria.

22. Parra, G., Vidales, G., Gomez, J., Fernandez, F., Parreno, V., Bok, K., 2008: Phylogenetic analysis of porcine rotavirus in Argentina: increasing evidence of interspecies transmission. Vet. Microbiol., 126, 243-350. DOI:10.1016/j.vetmic.2007.06.006.

23. Paul, P., Stevenson, G. W., 1992: Rotavirus and Reovirus. Diseases of Swine. 7th edn., Iowa State University press, Ames, USA, 331-348.

24. Prabha, S., Verghese, S., 2009: Detection of porcine rotavirus from tissue and fecal specimens. Indian Journal of Medical Microbiology, 27, 149-152. DOI: 10.4103/02550857.49430.

25. Steele, A. D., Geyer, A., Gerdes, G. H., 2004: Rotavirus infections. In Coetzer, J. A. W., Tustin, R. C.: Infectious Diseases of Livestock, Oxford University Press, Cape Town 2, 1256-1264.

26. Steyer, A., Poljšak-Prijatelj, M., Barlič-Maganja, D., Marin, J., 2008: Human, porcine and bovine rotaviruses in Slovenia: evidence of interspecies transmission and genome reassortment. J. Gen. Virol., 89, 1690-1698. DOI: 10.1099/vir.0. 2008/001206-0.

27. Svensmark, B., Askaa, J., Wolstrup, C., Nielsen, K., 1989: Epidemiological studies of piglet diarrhea in intensively managed Danish sow herds. IV. Pathogenicity of porcine rotavirus. Acta Vet. Scand., 30 (1), 71-76.

28. Thrusfield, M., 1997: Veterinary Epidemiology, 3rd edn., Blackwell Science Limited, London, 479 pp.

29. Tonietti, P., Silva, F., Hora, S. A., Gregori, F., 2013: Group A rotaviruses: an updated review. Journal of Scientific Research and Reviews, 2, 041-055. DOI: 10.1128/JCM.01175 
30. Tsugwa, T., Hoshino, Y., 2008: Whole genome sequence and phylogenetic analysis. reveal human rotavirus G3P [3] strains Ro1845 and HCR3A are examples of direct virion transmission of canine/feline rotaviruses in humans. Virology, 380, 344-353. DOI: 10.1016/j.virol.2008.07.041.

31. Weiler, L. H., Ilieff, A., Herbst, W., 2001: Prevalence of enteropathogens in suckling and weaned piglets with diarrhoea in Southern Germany. Journal of Veterinary Medicine, Series B. 48 (2), 151-159. DOI: 10.1111/j.1439-0450.2001.00431.x.

32. Wittum, T. E., Dewey, C. E., Hurd, H. S., Dargatz, D. A., Hill, G. W., 1995: Herd-and litter-level factors associated with the incidence of diarrhoea morbidity and mortality in piglets 1-3 days of age. Journal of Swine Health and Production, 3: 99-104.
33. Bányai, K., Kemenesi, G., Budinski, I., Földes, F., Zana, B., Marton, S., et al 2017: Candidate new rotavirus species in Schreiber's bats, Serbia. Infect. Genet. Evol., 48, 19-26. DOI: 10.1016/j.meegid.2016.12.002.

34. Estes, M. K., Greenberg, H. B., 2013: Rotaviruses. In Knipe, P., Howley, P.: Fields Virology, 6th edn., Wolters Kluwer Health/Lippincott Williams and Wilkins Philadelphia, PA, USA, 1347-1395.

35. Matthijnssens, J., Van Ranst, M., 2012: Genotype constellation and evolution of group a rotaviruses infecting humans. Curr. Opin. Virol., 2, 426-433. DOI: 10.1016/j.coviro.2012.04.007.

36. ICTV, International Committee on Taxonomy of Viruses, 2017: Master Species List 2017. Retrieved from https://talk.ictvonline.org/files/master-species-lists/m/msl/7185.

Received December 5, 2018

Accepted February 25, 2019 